\title{
Formation of Eutectic Carbides in the Structure of High-Purity White Cast Iron in the Forging Process
}

\author{
D. A. Sukhanov' ${ }^{1}$ L. B. Arkhangelsky² \\ ${ }^{1}$ ASK-MSC Company, Moscow, Russia \\ ${ }^{2}$ President Union Smiths, Moscow, Russia \\ Email:_suhanov7@mail.ru,tigram.korolev@mail.ru
}

How to cite this paper: Sukhanov, D.A. and Arkhangelsky, L.B. (2017) Formation of Eutectic Carbides in the Structure of High-Purity White Cast Iron in the Forging Process. Materials Sciences and Applications, 8, 351-360.

https://doi.org/10.4236/msa.2017.85024

Received: April 25, 2017

Accepted: May 22, 2017

Published: May 25, 2017

Copyright $\odot 2017$ by authors and Scientific Research Publishing Inc. This work is licensed under the Creative Commons Attribution International License (CC BY 4.0). http://creativecommons.org/licenses/by/4.0/

\begin{abstract}
It is found that the deformation of white cast iron under forging production is only possible with a minimum number of permanent impurities. The developed modes of high-temperature intermediate annealing facilitate the deformation of the forging under normal production conditions. It is shown that in the process of isothermal annealing of white cast iron begins the process of disintegration of ledeburite in the more stable eutectic carbides, providing technological plasticity for subsequent forging. The installed influence of the purity of white cast iron on the morphology of the excess carbides and their ability to divide. Studies the morphology of the excess eutectic carbides after melting, pre-annealing and after deformation forging. Discovered that after severe plastic deformation the structure of white cast iron becomes more stable, due to the appearance of eutectic carbides. It was determined that the deformed structure of white iron, because of its lack ledeburite component, was more identical with the structure of the alloy ledeburite steels. The data obtained can be used for making Damascus bladed weapons products, experiencing shock-variables loads.
\end{abstract}

\section{Keywords}

White Cast Iron, Damascus steel, Wootz, Ledeburitic Steel

\section{Introduction}

Plain white cast irons, due to the presence in its structure, the excess phase in the form of ledeburite, have high hardness and wear resistance, and have lower cost compared to ledeburitic steels. The generally accepted view is that the white cast iron without alloying elements, due to the low technological plasticity, has no 
future as a cutting tool [1]. In most cases, plain white cast irons are used as the subsequent steelmaking iron redistribution in the malleable grey cast iron.

In the modern sense, white cast iron is considered highly pure if as permanent impurities included: $\mathrm{Si}$ to $0.5 \%, \mathrm{Mn}$ to $0.8 \%, \mathrm{~S}$ to $0.02 \%, \mathrm{P}$ to $0.02 \%$. The deoxidation of the melt of silicon and manganese has a positive impact on the process of melting alloy in crucible method. Boiling is suppressed; the melt goes into a balanced condition, reduced dendritic and carbide heterogeneity. It is believed that a few tenths of a percent of silicon and manganese remaining after deoxidation of the melt, have no significant effect on the level of mechanical properties and do not affect the behavior of alloys during deformation. However, this statement is true for pro-eutectoid and eutectoid steels. White cast irons with excess phase in the form of ledeburite, the influence of impurities in the products of deoxidation has a more significant impact on the process of embrittlement during plastic deformation.

As is known, the boundary between white cast iron and steel is the presence in the structure of the free ledeburite. On technological properties, white cast iron has a low ability to plastic deformation by forging. Kashchenko [1] formulated the position thus: "This feature-the lack of malleability is distinguished in the practice of cast iron from steel." Most experts in the field of metallurgy shared this opinion. It is believed that the difficulties, which arise during plastic deformation of white cast iron, are associated with the presence in the structure of the free ledeburite. Under normal conditions by forging white cast iron crumbles under the hammer. From our point of view, ledeburite is not the main reason for the low technological plasticity.

In the first half of the XIX century Russian Metallurgist Anosov [2] was obtained by melting in a crucible the white cast iron from which through forging received the highest grade Damascus steel, such as Indian wootz. Anosov paid special attention to the purity of their crucible alloys. In 1868, Chernov in his famous report on the polymorphism of iron had argued [3] that the less impurities in the steel, the better its quality. Best steel in all times, in his opinion, is an Indian wootz. Moreover, here he says the following: "Research Anosov showed clearly that the mystery is allowed by the cleanliness of steel, and he, as you know, obtained the highest quality of Eastern Bulat (genuine Damascus steel)".

Note that the key word Anosov (1841) and Chernov (1868) sounded "clean steel". This idea would not let go of many researchers, resulting in several works [4] [5] [6] [7] was reported on the plastic deformation of high-purity alloys with a carbon content of from 2.0 to $3.5 \%$ under normal conditions by forging.

The aim of this work is structural investigation of the reasons for plasticity deformation of plain white cast irons under industrial conditions by forging.

\section{Materials and Methods}

Melting white cast irons was carried out in a vacuum furnace without deoxidation in the Federal State Unitary Enterprise (FSUE) I.P. Bardin Central Research Institute for Ferrous Metallurgy (Moscow). Capacity of the crucible was about 7 
$\mathrm{kg}$ (Figure 1). The chemical composition of the alloy was controlled with the help of optical emission spectrometer ARL 3460 type. The chemical composition and marking of the studied white cast irons were as following: B24A $(2.42 \% \mathrm{C}$, $0.092 \% \mathrm{Si}, 0.14 \% \mathrm{Mn}, 0.007 \% \mathrm{P}, 0.023 \% \mathrm{~S}$ and all the rest elements in hundredths and thousandths fractions); B27A $(2.78 \% \mathrm{C}, 0.021 \% \mathrm{Si}, 0.14 \% \mathrm{Mn}$, $0.006 \% \mathrm{P}, 0.022 \% \mathrm{~S}$ and all the rest elements in hundredths and thousandths fractions). For example, where B is white cast iron, 27 is $2 \%, 68 \% \ldots 2 \%, 78 \%$ carbon content, $\mathbf{A}$ is high quality.

The deformation of the alloys was performed on the hammer pneumatic MB412 with a weight falling on the moving parts, $150 \mathrm{~kg}$, intended for forging works by free forging in small-scale production. The temperature of the intermediate heating under forging was no more than $950^{\circ} \mathrm{C}-1000^{\circ} \mathrm{C}$ with an exposure of 15 minutes. The temperature of the end forging does not exceed $600^{\circ} \mathrm{C}$ $650^{\circ} \mathrm{C}$. The temperature of the beginning and end of forging was controlled by a pyrometer AKIP-9310. Time of the measuring cycle did not exceed 5 seconds.

The ingot was cut into several parts. The resulting workpiece weight 800 grams was subjected to deformation by forging. Cast billet is difficult to give plastic deformation (elastically dampen). However, after three passes at low speed the falling of the hammer with the rotation of the workpiece 90 degrees process was carried out much easier. As a result, strip thickness of $20 \mathrm{~mm}$ and $6 \mathrm{~mm}$ was obtained.

Structural investigations were carried out using an optical microscope of a series METAM RV-21-2 in the zoom range from 50 to 1100 fold. Deeper structural investigations were carried out on scanning electron microscope CarlZeissEV050XVP using microanalyzer EDS X-Act.

\section{Results and Discussion}

Our research in the field of converting non-alloy white cast iron into Damascus steel [8] showed that the permanent presence of impurities of silicon and manganese is harmful to their structures and properties. The presence of manganese about $0.6 \%$ reduces the growth of dendrites of austenite during solidification of the melt, promotes the release needles of Widmanstatten cementite (Figure

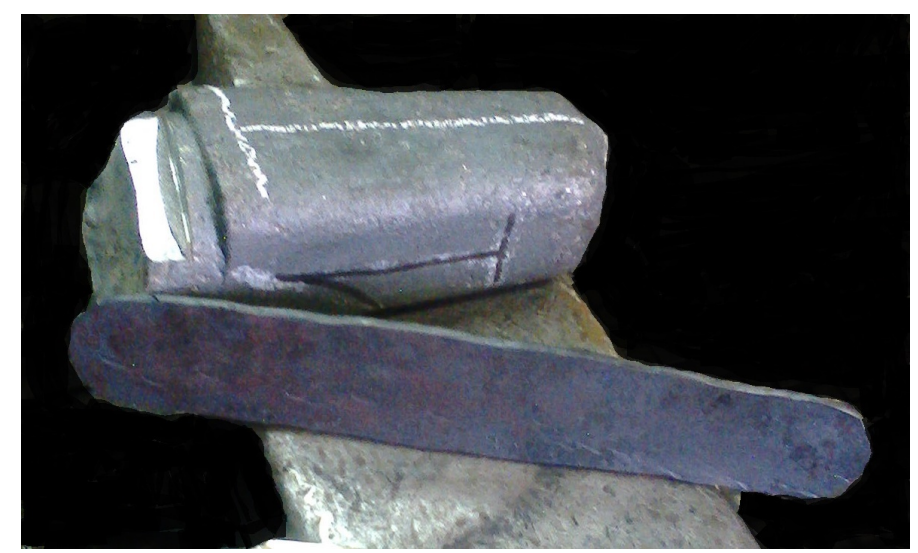

Figure 1. Crucible ingot and forged stripe thickness $6 \mathrm{~mm}$ alloy B27A. 
2(a)), and stabilizes pearlitic matrix during high temperature annealing. The presence of silicon in amount of about $0.4 \%$ greatly strengthens ferrite in pearlite and drastically lowers the ductility of the alloy during deformation. In addition, it promotes the formation of elements like brittle eutectic, which during longterm isothermal annealing is transformed into graphite (Figure 2(b)).

Research described in [8] indicates that the shape and size of the eutectic carbides formed during the fragmentation and partial recrystallization of ledeburite depend not only on the conditions of forging and heat treatment, but also from modifying additives. For example, after the deoxidation of the melt of silicon and manganese to $0.5 \%$, it is formed excess carbide phase in the form of lamellar-cellular ledeburite (Figure 3(a)).

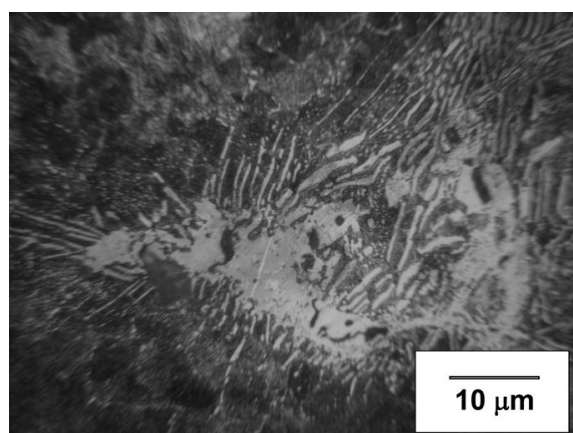

(a)

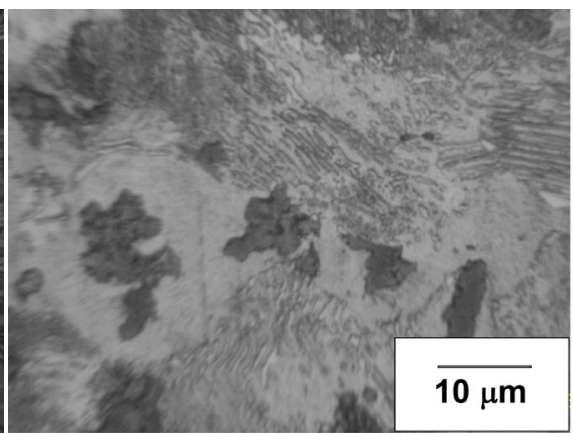

(b)

Figure 2. The deoxidation of the melt B27A manganese up to $0.6 \%$ (a) and silicon up to $0.4 \%(b)$.

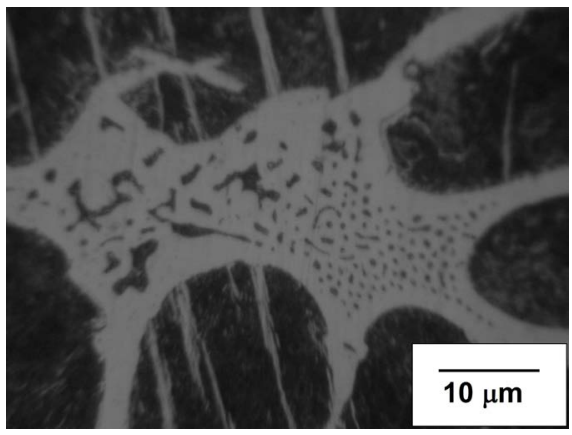

(a)

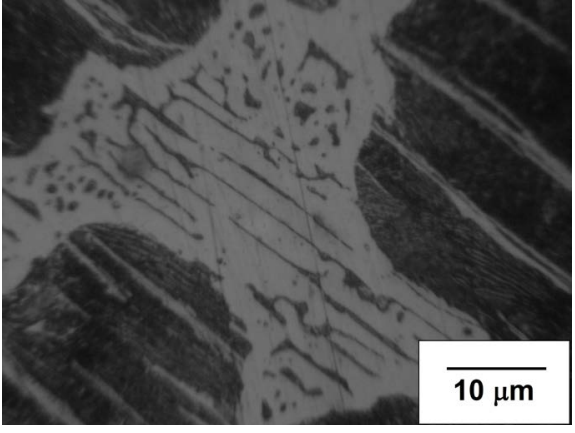

(b)

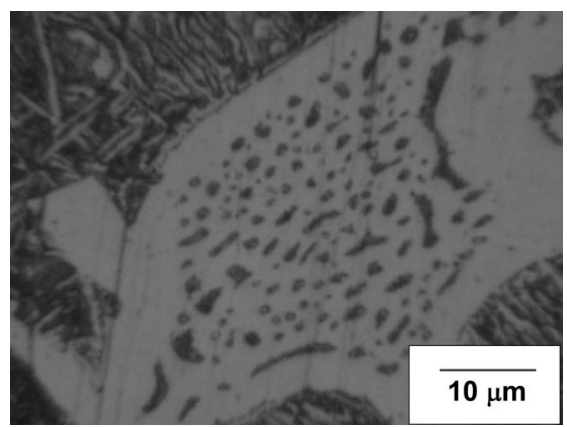

(c)

Figure 3. The morphology of ledeburite alloy B27A: (a) lamellar-cellular; (b) lamellar; (c) cellular. 
Introduction to aluminium melt to $0.10 \%$ contributes to the formation of white cast iron predominantly of lamellar ledeburite (Figure 3(b)). During crystallization melt, layered clusters of alumina $\left(\mathrm{Al}_{2} \mathrm{O}_{3}\right)$, located in interdendritic intervals, facilitate the excretion of excess cementite in the lamellar colonies of ledeburite.

In the case of modifying the melt of white cast iron to calcium up to $0.02 \%$, the structure of ledeburite predominantly cellular type is formed (Figure $3(c)$ ). Additionally, suppressed education Widmanstatten structure of cementite that promotes the formation of inclusions of globular shapeleads to increased viscosity.

Thus, using different modifiers you can get a white cast iron with a given various morphology ledeburite. Lamellar-cellular, lamellar or cellular morphological types of ledeburite during the deformation behaves differently. This fact should be taken into account when designing in technological parameters of the forging production.

Structure of high-purity white cast irons B24A and B27A after vacuum induction melting is fully consistent with the classical ideas. The number, size and branching of dendrites of austenite are determined by the cooling conditions. In this case, cooling of the alloy during solidification took place at an ambient temperature not exceeding $20^{\circ} \mathrm{C}$. Accordingly, the rate of cooling of alloys in ceramic crucibles did not exceed 1.5 degrees per second. Structure after solidification of the white cast iron B24A and B27A is a network of ledeburite, inside of which are distributed decomposition products of austenite: pearlite matrix, with randomly placed needles of Widmanstatten cementite. The structure of these alloys after vacuum melting is shown in Figure 4(a) Figure 4(b).

Metallographic analysis of the forged samples showed that the preform thickness $20.0 \mathrm{~mm}$ of alloys B24A and B27A has unfinished structure (Figures 5(a)$5(c)$ ). In samples deformed into a strip $6 \mathrm{~mm}$ thick, there is another picture. Ledeburite inclusion still presents, however, the cementite particles become more regular shape, without distinct acute angles (Figures 5(b)-5(d)). Properties of alloys with such a structure (Figures $5(\mathrm{~b})-5(\mathrm{~d})$ ) are still quite mediocre because of the heterogeneity of carbides excess phase.

To obtain stable results and set parameters of structures, in particular, so that all excess cementite in white cast iron after deformation has turned a stable carbide of equiaxed shapes, it is required to develop a technological cycle in preparation operation for forging.

We offer before forging of high-purity cast ingots of white cast iron to carry out an additional operation, which is a high temperature isothermal annealing.

In the literature, there is evidence on pre-annealing of high-carbon alloys with the aim of obtaining structures Damascus steel. So, in the work of Anosov [2] it was shown that after prolonged annealing, for three days, at a temperature of about $850^{\circ} \mathrm{C} . . .950^{\circ} \mathrm{C}$, cast steel may be converted to Damascus steel. In works [9] [10] [11], they described in detail the stages of the increase ductility of highcarbon alloys containing $2.25 \%$ carbon, in the during the high-temperature isothermal annealing. 


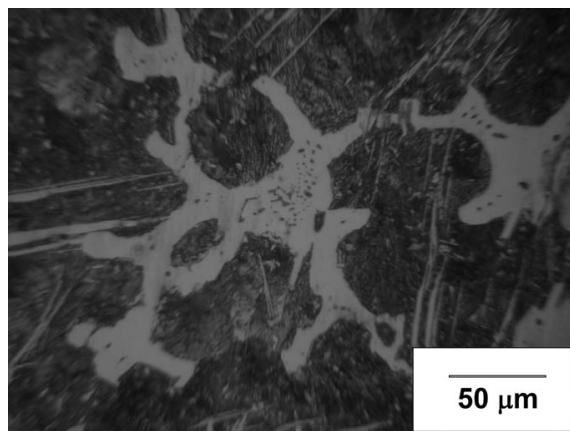

(a)

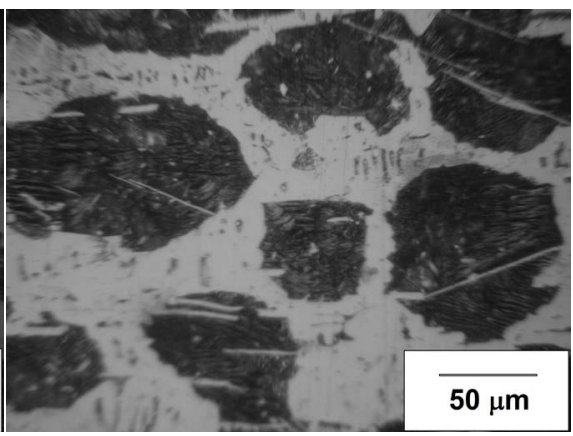

(b)

Figure 4. The structure of white cast iron after vacuum melting: (a) B24A; (b) B27A.

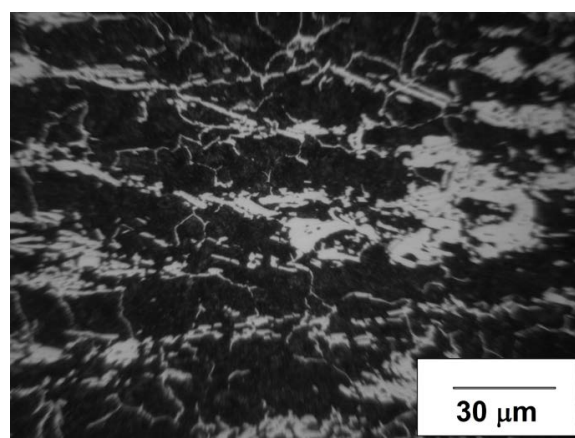

(a)

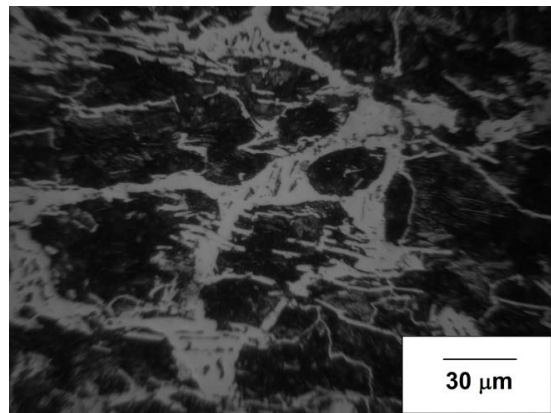

(c)

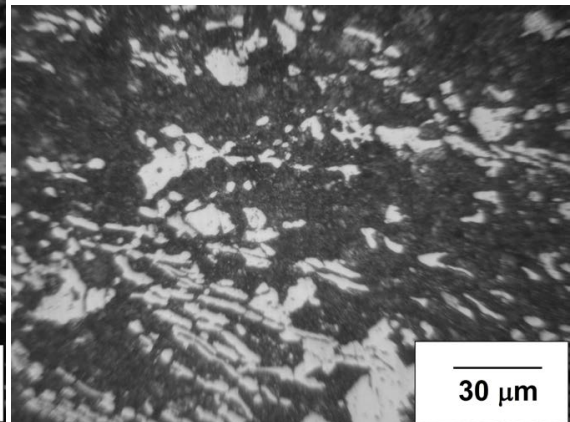

(b)

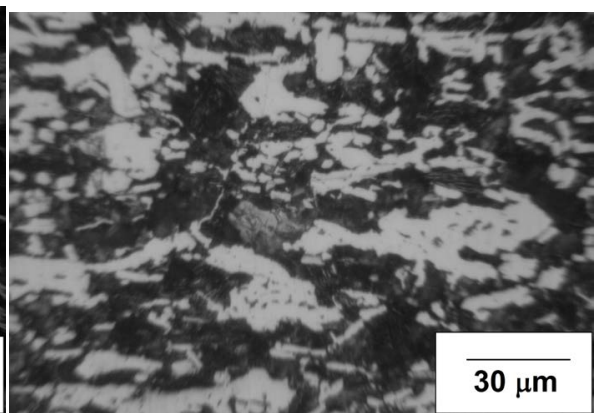

(d)

Figure 5. The structure of the deformed forging white cast iron: (a) strip $20 \mathrm{~mm}$ alloy B24A; (b) strip $6 \mathrm{~mm}$ alloy B24A; (c) strip $20 \mathrm{~mm}$ alloy B27A; (d) strip $6 \mathrm{~mm}$ alloy B27A.

The duration of isothermal exposure is directly connected with the annealing temperature. The higher the annealing temperature, the less time is needed for the activation of diffusion processes. In this work, the task was to reduce the time of isothermal exposure, increasing the annealing temperature.

The lower limit of the isothermal annealing, which we assume the temperature of the eutectoid decomposition, corresponds to $723^{\circ} \mathrm{C}$. At this temperature, the diffusion activity of carbon is very small. To obtain separate monolithic carbide formations will need long-term isothermal exposure, comprising more than 10 days. The upper limit of the isothermal annealing will take the temperature of the eutectic decay, for which high-purity white cast iron is around $1147^{\circ} \mathrm{C}$, which adversely affects the structural heredity of alloys for subsequent processing pressure. 
On the cast, samples of the alloy B24A were carried out with high-temperature annealing for 2 hours at a temperature of $840^{\circ} \mathrm{C}, 940^{\circ} \mathrm{C}, 1040^{\circ} \mathrm{C}$ and $1140^{\circ} \mathrm{C}$, in the sealed ceramic crucible, to prevent decarburization of the surface samples. The increasing annealing temperature, while the same duration of isothermal exposure, contributes to significant structural changes in the cast alloy B24A. The microstructure of annealed samples was presented in Figure 6(a)6(d).

After annealing at a temperature of $840^{\circ} \mathrm{C}$ for 2 hours, no visible changes in the morphology of the excess carbide phase are observed (Figure 6(a)). Forging of such a structure leads to the crushing network ledeburite (Figure 7(a)). In the structure of the deformed alloy ledeburite fragments remain in grain boundaries, which negatively affects the operational properties.

After annealing at a temperature of $940^{\circ} \mathrm{C}$ for 2 hours on the surface, excess cementite formed protrusions in the form of "spikes", which begins the process of spheroidizing (Figure 6(b)). The basis of this process is diffusional transfer of carbon from cementite convex sections with greater surface curvature to areas with less curvature of the surface. Smoothing sharp edges are observed in the ledeburite. Reduction of interfacial surfaces in the transition of lamellar cementite forms in round shape accompanied by a decrease in free energy, which leads to increased plastic properties of the alloy compared to annealed at $840^{\circ} \mathrm{C}$. Alloy structure after deformation is shown in Figure 7 (b). You can observe short plate form of secondary cementite along with fragments of the ledeburite eutectic. Properties of the deformed alloys with such a heterogeneous morphology of the excess carbide phase are still quite low.

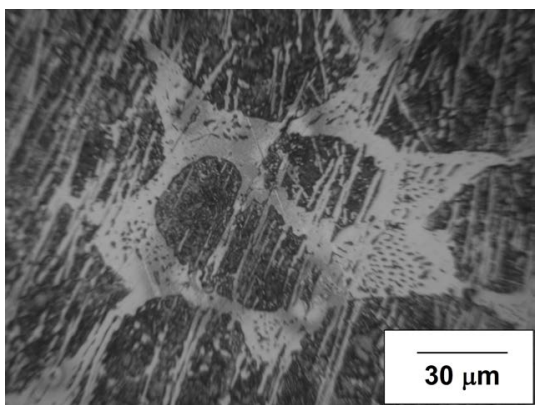

(a)

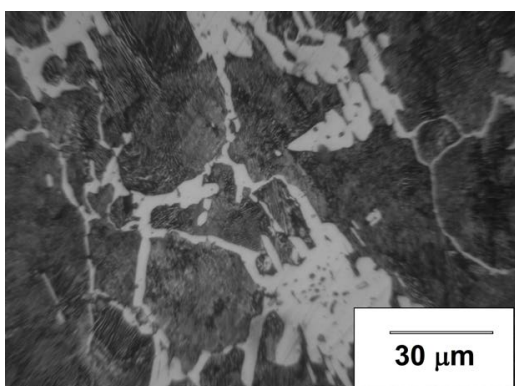

(c)

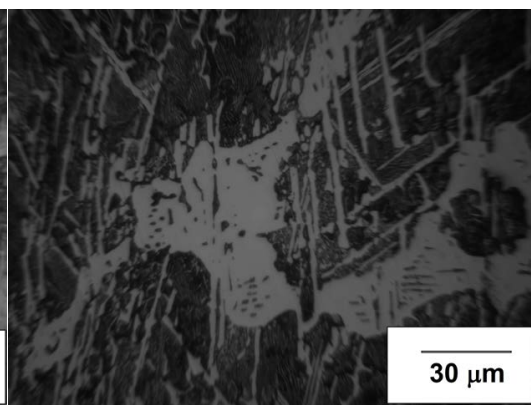

(b)

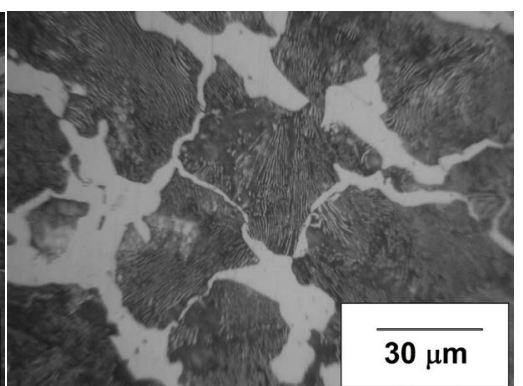

(d)

Figure 6. The structure of the alloy B24A after annealing (2 hours): (a) $840^{\circ} \mathrm{C}$; (b) $940^{\circ} \mathrm{C}$; (c) $1040^{\circ} \mathrm{C}$; (d) $1140^{\circ} \mathrm{C}$. 


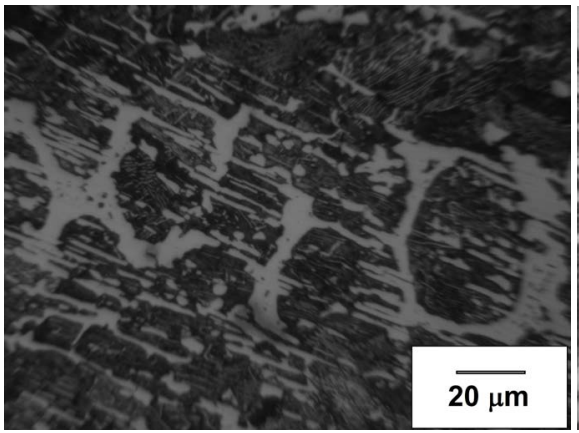

(a)

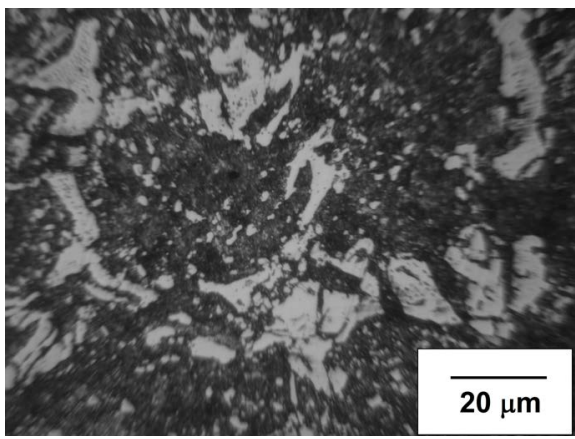

(c)

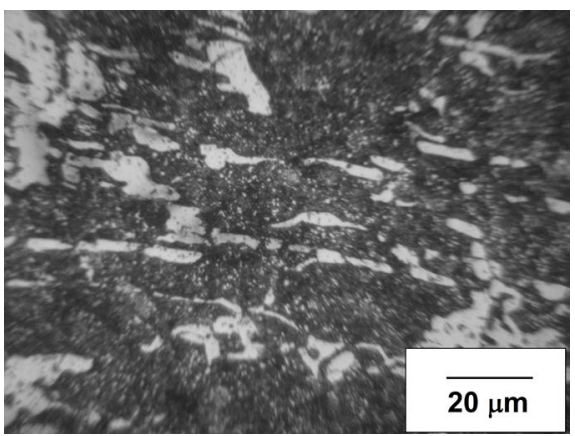

(b)

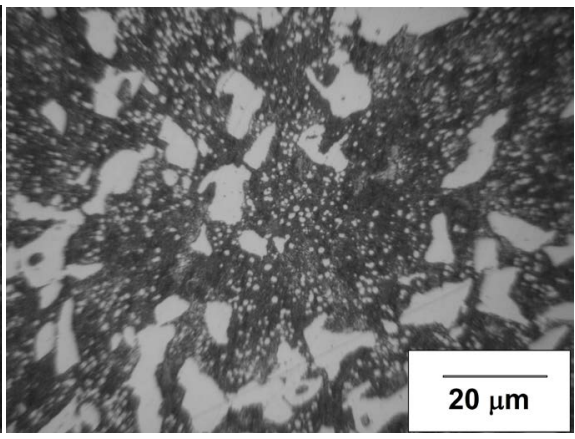

(d)

Figure 7. The structure of the deformed alloy B24A after isothermal annealing: (a) $840^{\circ} \mathrm{C}$; (b) $940^{\circ} \mathrm{C}$; (c) $1040^{\circ} \mathrm{C}$; (d) $1140^{\circ} \mathrm{C}$.

After annealing at a temperature of $1040^{\circ} \mathrm{C}$ for 2 hours in the structure alloys, the process of coalescence of excess carbides starts (Figure 6(c)). Especially favorable conditions for the dissolution of excess cementite particles are observed near the concave surface of the ledeburite colonies. In such places, the solubility of carbon in austenite is particularly small. On the boundaries of austenite grains, the carbon diffuses to ledeburite, stratifying on the edge of ledeburite colonies. Cementite particles near the surface of ledeburite gradually disappear. The interphase boundary between ledeburite austenitic and the matrix becomes less long. Maintaining in the structure of the alloy ledeburite colonies indicates the incompleteness of diffusion processes. To complete the diffusion process, with the aim of obtaining the structure of dense monolithic of carbide formation it is necessary to the increase the time of isothermal exposure. Deformation accelerates the process of turning ledeburite in more stable solid carbides (Figure 7 (c)). The process is accompanied by decrease in free energy due to the reduction of interfacial surface, thereby increasing the deformation plasticity.

Annealing high-pure white cast iron under $1140^{\circ} \mathrm{C}$ for 2 hours leads to compaction of ledeburite colonies (Figure 6(d)). Ledeburite transformation in the monolithic angular carbides is called "eutectic carbides". This process leads to a decrease in free energy in the white cast iron, facilitating the initial stage of deformation of the forging. Division of carbides occurs by shifting decarburization zones thermal fission. After subsequent severe plastic deformation, the structure of white cast iron becomes more stable, due to the emergence of separate mono- 
lithic carbides formations (Figure 7(d)). The education of carbide resembles the morphology of eutectic carbides die steels and high speed steels.

On the polished surface of a plate thickness of $6.0 \mathrm{~mm}$ made of deformable white cast iron (B27A) after etching in $4 \%$ solution $\mathrm{HNO}_{3}$ appears black-andwhite patterns (Figure 8(a)). Patterns are formed by the uneven distribution of the eutectic carbides with a volume fraction of $40 \%$ (Figure $8(\mathrm{~b})$ ). This pattern corresponds to the highest grades of Damascus steel-Wootz.

\section{Conclusions}

The ingots of white cast iron, with a content of $2 \%, 4 \% \ldots 2 \%, 8 \%$ carbon, cleansed from all impurities, can be subjected to an intensive forging under normal production conditions.

Preliminary high-temperature annealing will facilitate the deformation forging. This process step leads to a decrease in the interfacial surfaces, thereby reducing the free energy of the alloy as a whole and, accordingly, increasing the plasticity deformation in the forging process.

Deformation accelerates the process of turning ledeburite in a more stable solid carbides prismatic morphology (eutectic carbides). Eutectic carbides are thermally stable, as they do not dissolve into the austenite to temperature of the eutectic decay.

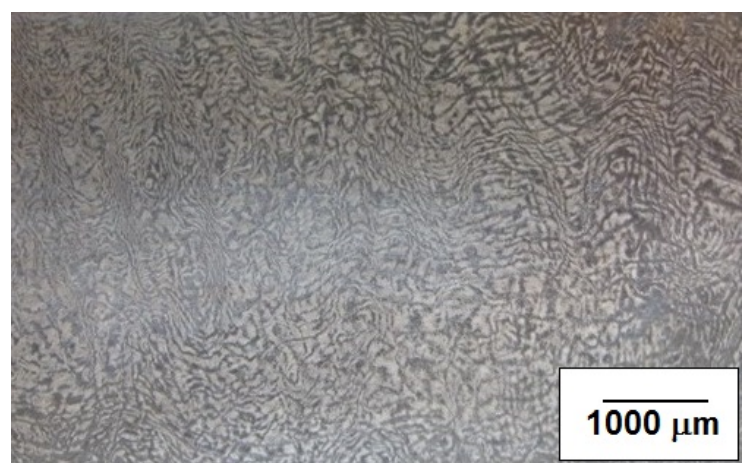

(a)

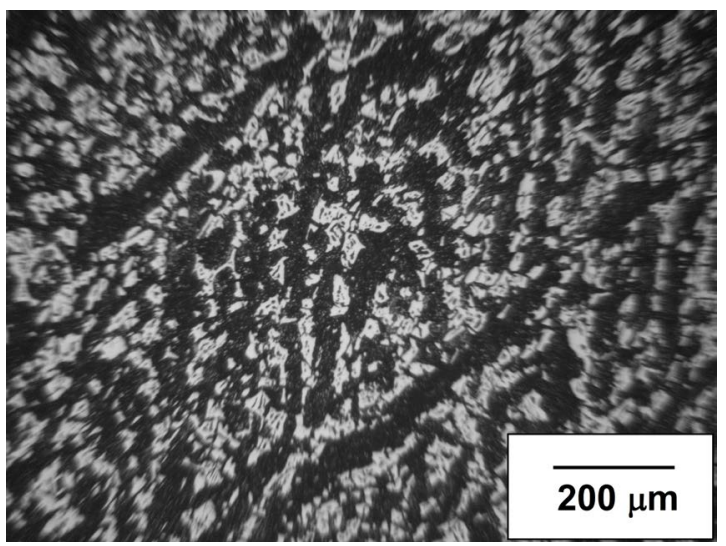

(b)

Figure 8. Macrostructure (a) and microstructure (b) of the deformed alloy B27A. 
The management of morphology formations of carbide in high-purity white cast irons, obtained by crucible melting and subsequent forging in a small batch forging production can be used for the manufacture of bladed weapons products, experiencing shock-variables loads.

\section{References}

[1] Kashchenko, G.A. (1957) The Basics of Physical Metallurgy. Mashgiz, Moscow, 395 p. (In Russian)

[2] Anosov, P.P. (1841) On the Bulat. Mining Journal, No. 2, 157-319. (In Russian)

[3] Sadowski, V.D. (1983) Chernov, D.K. Selected Works on Metallurgy and Physical Metallurgy. Science, Moscow, 447 p. (In Russian)

[4] Gaev, I.S. (1965) Damascus Steel and Modern Iron-Carbon Alloys. Metallovedenie I Termicheskaya Obrabotka Metallov_Metal Science and Heat Treatment, No. 9, 17-24. (In Russian)

[5] Schastlivtsev, V.M., Urtsev, V.N., Shmakov, A.V., Degtyarev, V.N., Nakonechnyi, A.Y., Mokshin, E.D. and Yakovleva, I.L. (2013) Structure of Bulat. Fizika Metallov I Metallovedenie-The Physics of Metals and Metallography, 114, 650-657. (In Russian) https://doi.org/10.7868/S0015323013070103

[6] Verhoeven, J.D. (1987) Damascus Steel, Part 1: Indian Wootz Steel. Metallograhpy, 20, 145-151.

[7] Hmara, L. and Serko, A. (1977) Tool of Bulat Steel [Tool of Damascus Steel]. Technology and Science, No. 7, 7-9. (In Russian)

[8] Sukhanov, D.A. and Arkhangelskiy, L.B. (2016) Damascus Steel Microstructure. Metallurgist, 59, 818-822. https://doi.org/10.1007/s11015-016-0178-X

[9] Sukhanov, D.A., Arkhangelskiy, L.B. and Plotnikova, N.V. (2016) The Morphology of the Carbides in High-Carbon Alloys such as Damascus steel. Metal Working and Material Science, 4, 43-51. https://doi.org/10.17212/1994-6309-2016-4-43-51

[10] Sukhanov, D.A. and Plotnikova, N.V. (2016) Wootz: Cast Iron or Steel? Materials Sciences and Applications, No. 7, 792-802.

[11] Sukhanov, D.A., Arkhangelskiy, L.B. and Plotnikova, N.V. (2017) Nature of Angular Carbides in Damascus Steel. Metallurgist, No. 1, 64-69.

Submit or recommend next manuscript to SCIRP and we will provide best service for you:

Accepting pre-submission inquiries through Email, Facebook, LinkedIn, Twitter, etc.

A wide selection of journals (inclusive of 9 subjects, more than 200 journals)

Providing 24-hour high-quality service

User-friendly online submission system

Fair and swift peer-review system

Efficient typesetting and proofreading procedure

Display of the result of downloads and visits, as well as the number of cited articles

Maximum dissemination of your research work

Submit your manuscript at: http://papersubmission.scirp.org/

Or contact msa@scirp.org 